$\mathrm{AJ} H$

Received : 14.02.2013

Accepted : 15.11.2014
THE ASIAN JOURNAL OF HORTICULTURE

Volume 9 | Issue 2 | Dec., 2014 |466-483

Visit us -www.researchjournal.co.in

\title{
Process of making - waste into wealth - dry flower technology
}

Members of the Research Forum

Associated Authors:

${ }^{1}$ Horticultural Research Station

(T.N.A.U.), Yercaud, SALEM DT. (T.N.) INDIA
Author for correspondence : A. SANKARI

Horticultural Research Station

(T.N.A.U.), Yercaud, SALEM DT.

(T.N.) INDIA

Email : sathatnau@yahoo.co.in

\section{A. SANKARI AND M. ANAND}

ABSTRACT : The growth of the niche market for arrangement has spawned a new industry in the floral handicrafts "the dry flowers". Presently this industry has become the fertile area and the mainstay for commercial exploitation. Drying flowers is an exotic physical process with the unique ability to preserve a life appearance and colour in beautiful blooms. Dried produce is sent to the processing units, which generally entail three treatments such as Drying, Bleaching and Dyeing. The techniques applied by dried flower processors are varied. Sometimes can be simply air dried while others must be treated with glycerine to prevent brittleness after drying. Freeze drying is now in vogue, being the latest state of art. Sulphur gas is used to fix the colour in some sp and many products are bleached and dyed according to the preferences (Anonymous, 1997). This paper is a step towards standardizing techniques of drying, bleaching and dyeing of dry flowers.

KEY WORDS : Dry flowers, Drying methods, Bleaching and dyeing

HOW TO CITE THIS ARTICLE : Sankari, A. and Anand, M. (2014). Process of making-waste into wealth-dry flower technology. Asian J. Hort., 9(2) : 466-483. 